\title{
THE INFLUENCE OF AUSTENITIZING TEMPERATURE LEVEL ON MICROSTRUCTURE DEVELOPMENT IN CHROMIUM LEDEBURITIC TOOL STEEL
}

\author{
Lukáš RAUSA, Juraj ĎURICA, Maroš MARTINKOVIČ, Roman ČIČKA, Matej PAŠÁK, Peter JURČI \\ ${ }^{1}$ Slovak University of Technology in Bratislava, Faculty of Materials Science and Technology in Trnava, \\ Trnava, Slovakia,EU, lukas.rausa@stuba.sk, juraj.durica@stuba.sk, maros.martinkovic@stuba.sk, \\ roman.cicka@stuba.sk,.p.jurci@seznam.cz
}

https://doi.org/10.37904/metal.2021.4155

\begin{abstract}
The main goal of this article is to present the results of state the microstructure in chromium ledeburitic tool steel commercially named Sverker 3 . This material was treated by austenitizing at various temperatures and then quenched in oil. Paper is focused on distribution and change in carbide particles depending on austenitizing temperature. Analysis was focused on population of these particles and classification particles by EDS analysis results and measuring of hardness. According to chemistry of particles were particle sorted by types. Beside that all results are compared to phase equilibrium calculated in Thermo-Calc.
\end{abstract}

Keywords: Ledeburitic tool steel, quenching, microstructure, carbide particles

\section{INTRODUCTION}

High alloy tool steels usually contain a higher carbon content and are mainly alloyed by Cr, W, V, Mo. [1]. High alloy tools steels were developed in order to achieve such important mechanical and physical properties like hardness, abrasive wear resistance [1,2,3] corrosion resistance and dimensional stability [1,4]. Hence, these steels are suitable for variety industrial operations such as cutting, forming [3], plastics moulds, measuring instruments, gauges and many others. [5]. Mechanical properties of tool steels are determined by their phase composition, microstructure, matrix and type, quantity, size and distribution of the carbides. The microstructure can be varied by the use of proper heat treatment procedure. In most cases, the tools made of ledeburitic steels are subjected to various hardening and tempering regimes. By applying these heat treatment schedules the soft ferrite/carbide microstructure is replaced by much harder martensite. Hence, also, the properties of steel can be modified by using the heat treatment in great extent [3]. Chromium ledeburitic steels contain higher level of carbon and chromium. Presence of these elements is mainly linked with precipitation of wide spectrum of carbide particles, mainly the $\mathrm{M}_{7} \mathrm{C}_{3}$. Morphology of carbide particles significantly affects the mechanical properties. These particles are able to improve wear resistance. On the other hand as first limitation in use is linked with higher number and higher sizes of certain kind of carbides which lowers a toughness or cause a sensitivity to fracture [4]. Higher austenitization temperatures are related to dissolution of carbides whose alloys are able to improve hardness of matrix. The second limitation occurs as the decrease of $M_{s}$ and $\mathrm{M}_{\mathrm{f}}$ temperatures is due to matrix saturation increase [6]. Among the main purposes of the current experiment belong revealing how the alloying elements were partitioned between phase constituents present in material. Besides that, it is necessary to compare hardness of specimens which correlate with distribution of chemical elements. The final goal is to determine the morphology, size and population of all the carbide particles and how these characteristics are influenced by the used heat treatment regimes. 


\section{METHODOLOGY AND RESEARCH}

The material used for experiment was commercially available ledeburitic tool steel Sverker 3 with chemical composition (in mass \%) 2.05 C, $0.3 \mathrm{Si}, 0.8 \mathrm{Mn}, 12.7 \mathrm{Cr}, 1.1 \mathrm{~W}$, and $\mathrm{Fe}$ as a balance. Cylindrical specimens with dimensions of $\Phi 16 \times 8 \mathrm{~mm}$ were cut off from steel bar. After that the specimens were subjected to conventional hardening procedure. It consisted of gradual heating up to the required austenitizing temperature, hold there for 25 minutes and quenched. The first ramp was chosen at $600{ }^{\circ} \mathrm{C}$ with a 10 minutes duration. After this stage the specimens were heated-up to final austenitization temperature, held there and subsequently oil-quenched. The level of the final austenitizing temperature was chosen from the range 900$1050{ }^{\circ} \mathrm{C}$, with a step of $25^{\circ} \mathrm{C}$. Microstructural analysis of specimens was carried out by scanning electron microscope (SEM). Before that the specimens were grinded by a set of abrasive papers with different size of abrasive (in order 220, 320, 600, 1200), and polished with various type of diamond suspensions (in order 9, 6, $3,1 \mu \mathrm{m}$ ). As an etchant $3 \%$ ethanol solution of picric acid (Picral) was used. For SEM analyses a JEOL 7600F scanning electron microscope coupled with energy dispersive spectroscope (hereinafter EDS) detector was used. Microstructural images were acquired at different magnifications, i.e. 1000x, 3000x and 5000x. Chemical composition of carbide particles and the matrix was estimated by EDS analyser. Hardness measurements were performed by Vickers method, at a load of $98.1 \mathrm{~N}$ (HV10), by using a ZWICK 3212 hardness tester. For verification of the reliability of the obtained results they were compared with calculated phase equilibria for the given system, by using a ThermoCalc 2021 software. Quantitative analysis of microstructure was focused to determine the number of carbide particles. The measurements were performed on areas of $10 \times 10 \mu \mathrm{m}$. In order to ensure statistical consistency, the input data were averaged from 5 measurements for each specimen. Among the main parameters: the mean number of microparticles per volume unit $-N_{k}\left(1 / \mathrm{mm}^{3}\right)$, mean interparticle spacing $I_{A}(\mu \mathrm{m})$, calculated according formulas in [7] and quantity of carbides (\%) evaluated by point method [6,7].

\section{RESULTS AND DISCUSSION}

\subsection{As-received state}

The examined steel was delivered in a state after soft-annealing. The steel in this state contains non-uniformly distributed, irregularly shaped eutectic carbides, almost uniformly distributed quasi-globular secondary carbides and uniformly distributed eutectoid carbides. Carbides are distributed in ferritic matrix [3,5,8]. From the point of view of chemistry three types of carbide particles were determined by EDS measurements, further denoted as $\mathrm{K} 1, \mathrm{~K} 2$ and $\mathrm{K} 3$. These carbides are different from the point of view of their origin, which is reflected in their chemical composition. The average chemical compositions of these particles (in mass percent) are shown in Table 1. With respect to computed equilibrium, Figure 1a one can assume the presence of major amount of $\mathrm{M}_{7} \mathrm{C}_{3}$ and minor amount of $\mathrm{M}_{23} \mathrm{C}_{6}$ phases $[6,8,9]$. Besides that, one would also expect also the presence of $\mathrm{M}_{3} \mathrm{C}_{2}$ (see Figure 1a). But, in real situation the diffusion rate is very low below the characteristic $A_{1}$ temperature, hence, the presence of $\mathrm{M}_{3} \mathrm{C}_{2}$ is very unlikely. As mentioned in [10] steels of $D$-type are characteristic by presence of $\mathrm{M}_{7} \mathrm{C}_{3}$ particles and maximum iron content in $\mathrm{M}_{7} \mathrm{C}_{3}$ is around $50 \%$. This statement corresponds to the results in Table 1 for $\mathrm{K} 1$ and $\mathrm{K} 3$ types. The mean spherical diameter of the $\mathrm{K} 1$ - carbide particles in range between 2.5-22 $\mu \mathrm{m}$. It corresponds to the findings in [9] where author found $\mathrm{M}_{7} \mathrm{C}_{3}$ particles with maximal diameter approx. $21.5 \mu \mathrm{m}$. Correspondingly, the K2 - carbides have a size from the range 0.35$1.4 \mu \mathrm{m}$ and K3 - particles have a size in range $0.3-1.9 \mu \mathrm{m}$. The origin of K3 small particles $(0.05-0.52 \mu \mathrm{m})$ is very likely in the eutectoid transformation. In many cases these particles are spherically-shaped, which is highly expected shape in specimens after soft-annealing [11]. According to EDS, a slightly lower chromium content was found in these particles. The measured bulk-hardness was $245 \mathrm{HV} 10$, which is expected value for similar tool steels. 
Table 1 Categorization of carbides by chemical composition obtained by EDS (mass \%)

\begin{tabular}{|l|c|c|c|c|c|}
\hline & C & Cr & Mn & Fe & W \\
\hline Carbide K1 & $11.11 \pm 0.41$ & $42.7 \pm 0.41$ & $1.33 \pm 0.1$ & $42.71 \pm 0.37$ & $2.15 \pm 0.25$ \\
\hline Carbide K2 & $7.8 \pm 0.65$ & $18.72 \pm 4.42$ & $1.39 \pm 0.38$ & $64.12 \pm 6.64$ & $7.89 \pm 2.25$ \\
\hline Carbide K3 & $10.30 \pm 1.07$ & $31.5 \pm 5.33$ & $1.3 \pm 0.16$ & $54.82 \pm 6.36$ & $1.92 \pm 0.31$ \\
\hline
\end{tabular}
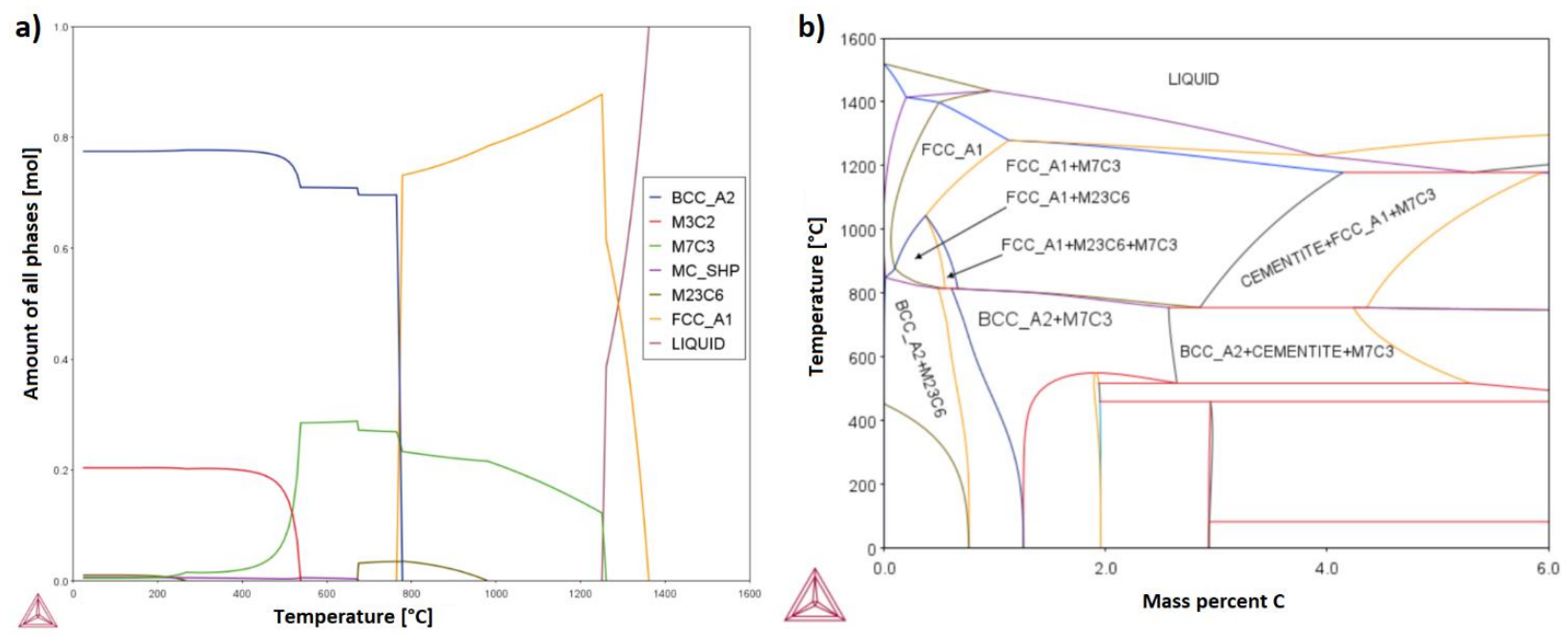

Figure 1 a) Calculation of phase equilibrium in temperature range $0-1600^{\circ} \mathrm{C}$, b) Fe-C-Cr phase diagram

\subsection{As-quenched state: matrix}
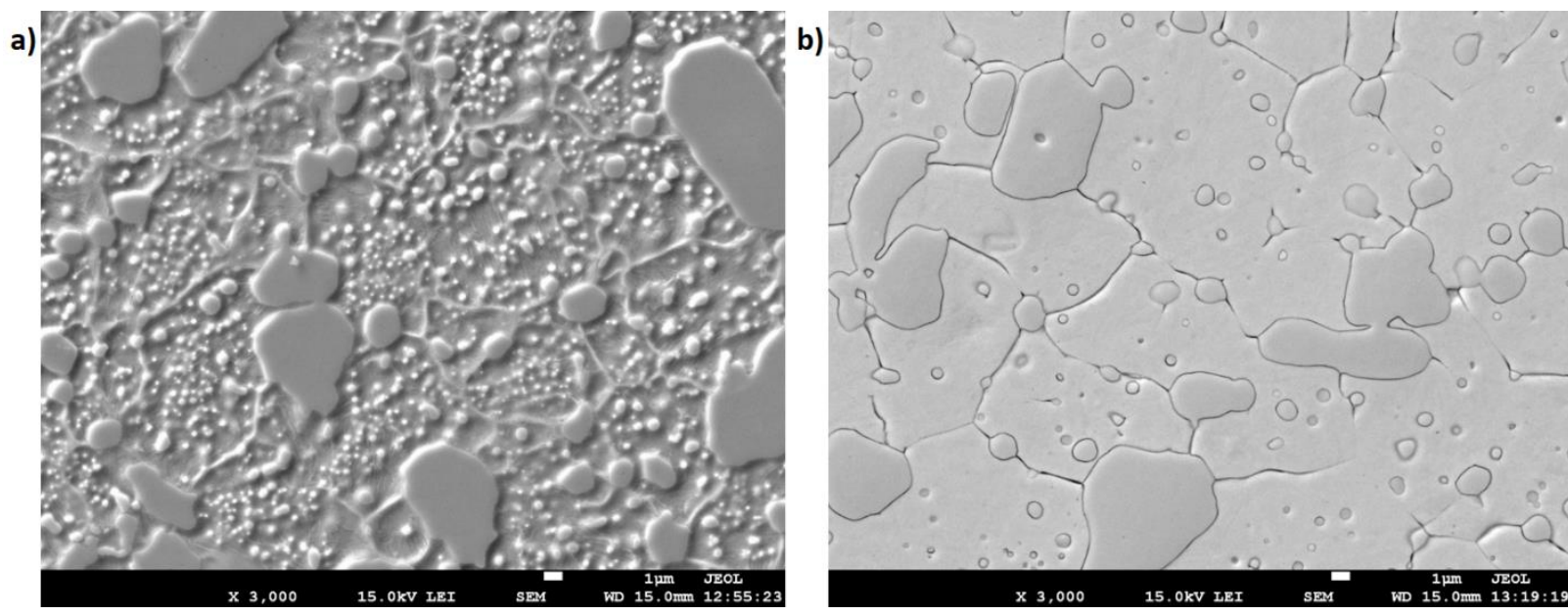

Figure 2 SEM micrographs of samples treated at different austenitization temperature a) $900{ }^{\circ} \mathrm{C}$, b) $1050{ }^{\circ} \mathrm{C}$

After application of austenitization and quenching procedure, the microstructure of the material has been changed from ferritic/carbidic to martensitic/carbidic, with a presence of certain amounts of retained austenite, as Figure 2 illustrates. Increasing the austenitizing temperature induces more pronounced saturation of matrix with alloying elements. The matrix was saturated mainly with the chromium, carbon and tungsten, Table 3. An optimal matrix saturation level is an important factor that influences the as-quenched hardness as well as the secondary hardenability of this kind of material. Together with increasing content of alloying elements in matrix, the characteristic $M_{s}$ and $M_{f}$ temperatures become lower [8,12]. This results in increase in amount of retained austenite in as-quenched steel microstructure [12]. The retained austenite is soft phase, hence the specimens treated above $1000{ }^{\circ} \mathrm{C}$ have lower hardness than those treated at $1000^{\circ} \mathrm{C}$ (Table 2). The main source of the 
saturation of the matrix is the dissolution of carbide particles [10]. Figure 3 shows that increasing the austenitizing temperature reduces the number of carbides. The most significant difference in number of carbide particles is between specimens treated at $975^{\circ} \mathrm{C}$ and $1000^{\circ} \mathrm{C}$. By comparing the micrographs in Figure 2 it is possible to observe that the main decrease in population of particles occurred inside original austenitic grains. There are situated mainly fine particles of K2 and K3 types.

\subsection{As-quenched state: carbides}

By the calculation of phase equilibrium (Figure 1a), it is very likely to expect two types of carbides in this steel system in the as-quenched state. The first one is the major $\mathrm{M}_{7} \mathrm{C}_{3}$ phase and the second (but minor) phase is $\mathrm{M}_{23} \mathrm{C}_{6}[6,8]$. The third carbide (K3) identified by EDS is very likely other crystal modification of $\mathrm{M}_{7} \mathrm{C}_{3}$. Fukaura proved a presence of $\mathrm{M}_{7} \mathrm{C}_{3}$ as white large particles and $\mathrm{M}_{23} \mathrm{C}_{6}$ as small black round particles in AISI D2 steel. However, this assumption should be confirmed by further analysis. As abovementioned, the carbides of K1 type have greater size $(2.5-22 \mu \mathrm{m})$, and are situated on the grain boundaries. In many cases the $\mathrm{K} 1$ have irregular or angular shape, very similar to rod and rectangles $[3,6,8,10,13]$. Besides that, the same chemical composition was also identified for smaller-sized particles which have mostly quasi-globular shape [13]. The largest particles belong to the eutectic carbides. In similar $\mathrm{Cr}$-steels, a presence of $\mathrm{M}_{7} \mathrm{C}_{3}$ phase is very common phenomenon. These carbides are stable up to the solidus temperature, hence, they were not affected by the applied heat treatment. The K2 carbide particles have much smaller size $(0.35-1.4 \mu \mathrm{m})$, predominantly globular shape, and are situated inside original austenite grains $[14,15]$. Their nature is originated probably by the fact that, they are formed due to the decreasing carbon/chromium solubility in the austenite. Therefore, one can call them as secondary carbides. According to Fe-C-Cr diagram (Figure 1b), it is clearly visible that $\mathrm{M}_{23} \mathrm{C}_{6}$ phase is expected mainly in carbon-depleted zones. By comparing the carbon contents in $\mathrm{K} 1$, $\mathrm{K} 2$ and $\mathrm{K} 3$ (Table 1), the $\mathrm{K} 2$ particles are very likely $\mathrm{M}_{23} \mathrm{C}_{6}$. The $\mathrm{K} 3$ carbides have similar size like $\mathrm{K} 2(0.3-1.9 \mu \mathrm{m})$ but they are elongated or quasi-globular shaped, and are situated inside the grains and as well as at the grain boundaries. A part of these particles may also belong to the group of secondary carbides. At higher austenitizing temperatures, more small-sized carbides were dissolved but large-size angular particles remain unaffected. The first significant decrease in population density of carbides was observed in specimens treated at $925^{\circ} \mathrm{C}$. This is because at $900^{\circ} \mathrm{C}$ only very fine particles inside the original austenitic grains start to dissolve. The second significant carbides count decrease occurred in specimens treated between 975 and $1000{ }^{\circ} \mathrm{C}$. According to Figure 1a, the complete dissolution of $\mathrm{M}_{23} \mathrm{C}_{6}$ is expected within this range, and certain decrease of $\mathrm{M}_{7} \mathrm{C}_{3}$ secondary carbides can also occur. In Figure 2 it is possible to see that the most pronounced decrease in carbide particles count was observed for small-eutectoid carbides. These particles are mostly situated inside original austenitic grains but some of them appear also on the grain boundaries. To validate the measured changes in carbide count a Thermo-Calc calculations were used. The results in Figure 1a clearly indicate a good agreement between measured values of carbide particles counts and theoretically predicted ranges of dissolution of individual carbide phases in the austenite.

Table 2 Hardness of specimens depending on the austenitization temperature

\begin{tabular}{|r|cc|}
\hline \multicolumn{3}{|c|}{ Hardness HV10 } \\
\hline soft-annealed & 245.00 & \pm 1.63 \\
\hline $900^{\circ} \mathrm{C}$ & 687.00 & \pm 4.24 \\
\hline $925^{\circ} \mathrm{C}$ & 772.00 & \pm 16.33 \\
\hline $950^{\circ} \mathrm{C}$ & 788.67 & \pm 4.71 \\
\hline $975^{\circ} \mathrm{C}$ & 854.33 & \pm 5.19 \\
\hline $1000^{\circ} \mathrm{C}$ & 898.33 & \pm 6.13 \\
\hline $1025^{\circ} \mathrm{C}$ & 882.00 & \pm 9.80 \\
\hline $1050^{\circ} \mathrm{C}$ & 806.33 & \pm 4.71 \\
\hline
\end{tabular}


Table 3 Development of the content of chemical elements in matrix depending on austenitization temperature.

\begin{tabular}{|c|c|c|c|c|c|c|c|c|c|c|c|c|}
\hline & \multicolumn{2}{|c|}{$C$ (wt.\%) } & \multicolumn{2}{|c|}{ Si (wt.\%) } & \multicolumn{2}{|c|}{$\operatorname{Cr}(w t . \%)$} & \multicolumn{2}{|c|}{$\mathrm{Mn}$ (wt.\%) } & \multicolumn{2}{|c|}{ Fe (wt.\%) } & \multicolumn{2}{|c|}{$\mathrm{W}$ (wt.\%) } \\
\hline led & 2.15 & \pm 0.18 & 0.59 & \pm 0.03 & 4.34 & \pm 0.99 & 0.78 & \pm 0.07 & 91.02 & \pm 1.24 & 1.12 & \pm 0.4 \\
\hline $900^{\circ} \mathrm{C}$ & 2.62 & 45 & 0.54 & 36 & 4.83 & 34 & .94 & \pm 0.09 & 89.61 & \pm 1.9 & .6 & \\
\hline & 2.5 & 4 & 58 & & 5.4 & & .85 & 08 & 51 & & 9 & \\
\hline${ }^{\circ} \mathrm{C}$ & 3.2 & \pm 0.19 & 0.55 & \pm 0.02 & 5.42 & \pm 0.63 & 0.79 & \pm 0.01 & 88.62 & \pm 1.15 & 1.5 & .1 \\
\hline $975^{\circ} \mathrm{C}$ & 2.98 & \pm 0.5 & 0.6 & \pm 0.05 & 5.82 & \pm 0.34 & 0.89 & \pm 0.05 & 88.37 & \pm 0.92 & 1.17 & \pm 0.22 \\
\hline $00^{\circ} \mathrm{C}$ & 2.68 & \pm 0.09 & 0.61 & \pm 0.04 & 5.62 & \pm 0.35 & 0.8 & \pm 0.13 & 89.06 & \pm 0.43 & 1.18 & \pm 0.2 \\
\hline $5^{\circ} \mathrm{C}$ & 2.65 & \pm 0.13 & 0.58 & \pm 0.03 & 6.43 & \pm 0.18 & 0.88 & \pm 0.05 & 88.17 & \pm 0.36 & 1.29 & \pm 0.1 \\
\hline $1050^{\circ} \mathrm{C}$ & 2.86 & \pm 0.43 & 0.55 & \pm 0.03 & 7.2 & \pm 1.12 & 0.9 & \pm 0.05 & 87.2 & \pm 1.48 & 1.29 & \pm 0.12 \\
\hline
\end{tabular}

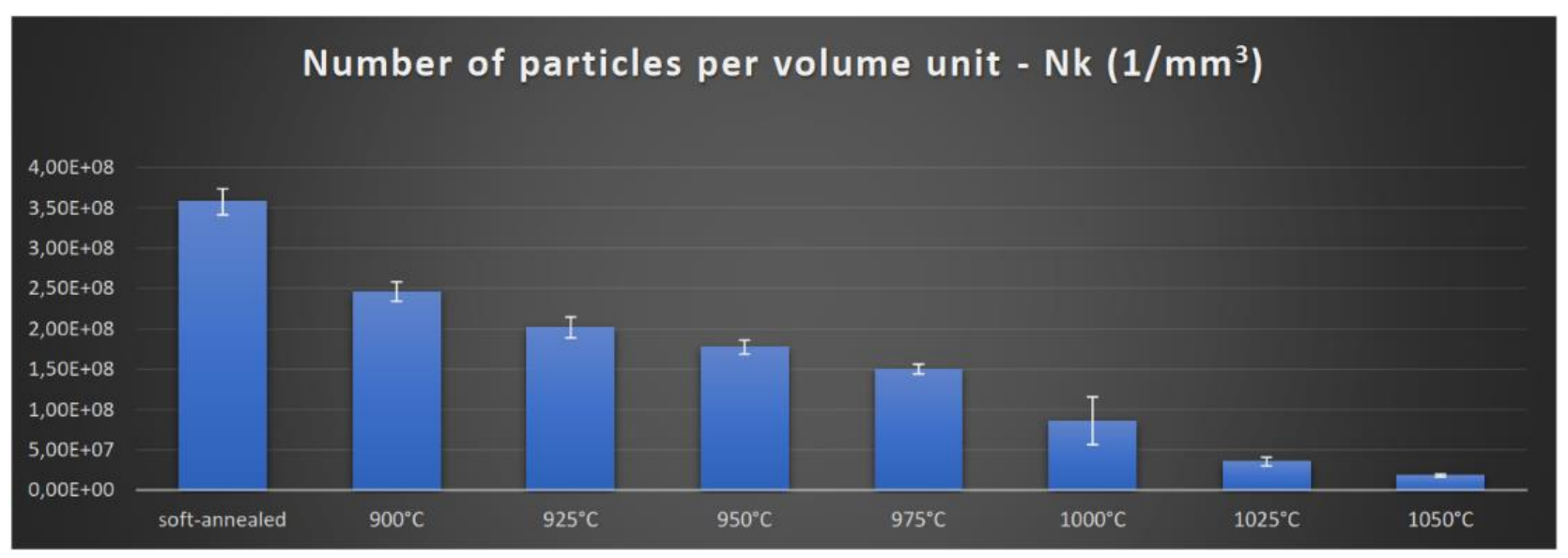

Figure 3 Number of particles per volume unit depending on the austenitization temperature

\section{CONCLUSIONS}

Based on the results of the study, the following conclusions can be formulated:

- $\quad$ Three carbide types were identified in examined steel. The largest K1 particles were eutectic carbides. They have angular shape, and are non-uniformly distributed in the matrix mainly at the grain boundaries. The K2 and K3 particles were much smaller, and manifested uniform distribution inside the grains as well as at the grain boundaries. They were detected as secondary phases but a part of them is also formed by eutectoid transformation.

- $\quad$ The $\mathrm{K} 1$ and $\mathrm{K} 3$ carbides contain high amounts of Fe and $\mathrm{Cr}$. The secondary $\mathrm{K} 2$ carbides also contain mainly these two elements but also enhanced amount of tungsten.

- $\quad$ The matrix of as-received state contained approx. $4 \% \mathrm{Cr}$ and minor portions of other elements like Si, $\mathrm{Mn}$ and $\mathrm{W}$. Heat treatment increased the amounts of $\mathrm{Cr}$ and $\mathrm{W}$ in the matrix while the amounts of $\mathrm{Mn}$ and $\mathrm{Si}$ were practically unaffected. The variations in amounts of different elements are related to the dissolution of different carbides in the austenite.

- The dissolution of eutectoid and secondary carbides results in decrease in the number of particles and in increase in the interparticle spacing.

- $\quad$ Saturation of the matrix caused increase in material hardness. But, the hardness increased only up to the austenitization temperature of approx. $1000^{\circ} \mathrm{C}$. Above $1000^{\circ} \mathrm{C}$ the hardness rather decreased due to higher amounts of retained austenite maintained in microstructure. 


\section{ACKNOWLEDGEMENTS}

The authors would like to acknowledge that the article is an outcome implementation of the following two projects: scientific project VEGA 1/0112/20 and APRODIMET, ITMS: 26220120048, supported by the Research \& Development Operational Programme funded by the European Regional Development Fund.

\section{REFERENCES}

[1] MACHEK, V., SODOMKA, J. Nauka o materiálu. 3.čast - Speciální kovové materiály. ČVUT v Praze, 2008. ISBN 978-80-01-04212-0.

[2] GERENGI, H., ARSLAN, Y., KURTAY, M. The effects of cryogenic treatment on the corrosion of AISI D3 steel. Material Research. 2015; vol. 18, no. 3, pp. 569-574. Available from: https://doi.org/10.1590/1516-1439.349914.

[3] PAŠÁK, M., ČIČKA, R., BÍLEK, P., JURČI, P., ČAPLOVIČ, L'. Study of phase transformation in Cr-V steel. Materials and technology. 2014, vol. 48, pp. 5 693-696. ISSN 1580-2949.

[4] DUDOVA, N., KAIBYSHEV, R. On the precipitation sequence in a $10 \% \mathrm{Cr}$ Steel under tempering. ISIJ International. 2011, vol. 51, no. 5, pp. 826-831.

[5] FÁBIÁN, E., R., TÓTH, L., HUSZÁK, C. Examination of heat treatment in the microstructure and wear of tool steels. Acta Materialia Transylvanica 2/2. 2019, pp. 87-92. Available from: https://doi.org/10.33924/amt-2019-0204.

[6] DAS, D., DUTTA, A.P., RAY, K.K. Sub-zero treatments of AISI D2 steel: Part I. Microstructure and hardness. Material Science and Engineering A. 2010, vol. 527, pp. 2182-2193. Available from: https://doi.org/10.1016/j.msea.2009.10.070.

[7] MARTINKOVIČ, M. Kvantitatívna analýza štruktúry materiálu. Nakladatel'stvo STU v Bratislave, 2011. ISBN 97880-227-3445-5.

[8] SUCHÁNEK, J. Abrasive wear of heat treated chromium ledeburitic steels. IN-TECH 2011. September 2011, vol.1.

[9] FUKAURA. K., YOKOYAMA, Y., YOKOI, D., TSUJII, N., ONO, K. Fatigue of cold-work tool steels: Effect of heat treatment and carbide morphology on fatigue crack formation, life, and fracture surface observation. Metallurgical and materials Transaction A. April 2004, vol. 35A, pp.1289-1300.

[10] KHEIRANDISH, S., SAGHAFIAN, H., HEDJAZI, J., MOMENI, M. Effect of heat treatment on microstructure of modified cast AISI D3 cold work tool steel. Journal of iron and steel research, International. 2010, vol. 17, no. 9; pp. $40-45,52$.

[11] LI, Z-X., LI, CH-S., ZHANG, J., QIAO, B., LI, Z-Z. Effects of annealing on carbides size and distribution and cold formability of $1.0 \mathrm{C}-1.5 \mathrm{Cr}$ bearing steel. Metallurgical and Materials Transactions A. July 2015. Available from: https://doi.org/10.1007/s11661-015-2904-6.

[12] JURČI, P. Structural changes in Cr-V ledeburitic steel during austenitizing and quenching. Materials Engineering, 2010, vol. 17, no.1.

[13] HRYNIEWICZ, T., NYKIEL, T. Fluctuations in chemical composition of $\mathrm{M}_{7} \mathrm{C}_{3}$ carbides in the soft annealed NC11LV/D2 steel. Advances in materials science. March 2014, vol.14, no.1, pp. 39. Available from: https://doi.org/10.2478/adms-2014-0003.

[14] HERNAS, A., GRZEGORZ, M., KINGA, R. Properties and microstructure of $12 \% \mathrm{Cr}-\mathrm{W}$ steels after long term service. Journal of Achievements of Materials and Manufacturing Engineering. April 2006.

[15] TKACHEV, E.S., BELYAKOV, A.N., KAIBYSHEV, R.O. The Role of deformation in coarsening of $\mathrm{M}_{23} \mathrm{C}_{6} \mathrm{Carbide}$ particles in 9\% Cr steel. Physics of Metals and Metallography. 2020, vol. 121, no. 8, pp. 804-810. ISSN 0031918X. 